\title{
Twenty-Eighth Annual Meeting, June 1999
}

The Twenty-eighth Annual Meeting of the College was held at the International Convention Centre. Birmingham, on 28 June-3 July 1999.

\section{Business meeting}

The Business Meeting of the Royal College of Psychiatrists was held on Thursday 1 July 1999 and was chaired by the President, Dr Robert Kendell. It was attended by 123 members of the College.

The minutes of the previous meeting held in Belfast on 24 June 1998 were approved and signed.

The Report of the President was received. Included in this Report was a proposal to extend Bye-Law III 2(ii) to enable doctors on the Specialist Register of the General Medical Council or the Irish Medical Council and consultants in the NHS to apply for membership of the College without examination. At present, ByeLaw III 2(ii) allowed exemption from all parts of the examination for up to eight medical graduates of exceptional distinction in any year up to a limit of 100 at any one time. It was therefore recommended that a third paragraph should be added to this Bye-Law as follows:

"qualified medical practitioners who are on the Specialist Register of the General Medical Council or the Irish Medical Council and who are in specified grades prescribed by the Regulations up to a limit of 50 per year and 500 at any one time."

The following resolution was proposed by $\mathrm{Dr}$ Robert Kendell, President and seconded by Dr Mike Shooter, Registrar:

That the Bye-laws of the College be amended, revoked and added in accordance with the copy thereof containing such amendments, revocations and additions sent to the Members with the notice of this Meeting provided that such amendments, revocations or additions shall not take effect until the same shall have been approved by the Privy Council and provided further that the Executive and Finance Committee of the Councll shall have authority to approve any further amendments required thereto by the Privy Council.

Pursuant to Paragraph 12 of the Supplemental Charter of the College the said resolution is to be approved by a majority of not less than two-thirds of the Members of the College present and voting at the Meeting.
It was also proposed that, in common with many other Medical Royal Colleges, the College should no longer circulate to its membership a full copy of the annual accounts, but that in future only a summary, together with pie-charts showing income and expenditure should be circulated. Full copies of the annual accounts would be available to any member of the College upon request. This was supported.

The Report of the Registrar and the Annual Report were received and approved. The Report of the Treasurer and the Annual Accounts for 1998, as given in the College's Annual Report, were received and approved. The re-appointment of the auditors was approved. The new fees and subscription rates from 1 January 2000 were approved. The Report of the Dean was received. The Report of the Editor was received. The Report of the Librarian was received.

\section{President's Report}

The President reported on a range of issues with important implications for the College and its members. 'Revalidation' was clearly a major issue for the whole profession and the General Medical Council (GMC) had committed itself to producing detailed proposals by November 2000 . All the medical Royal Colleges were determined to play a central role in revalidation, but it was still unclear whether they would participate in the assessment of all doctors or only of a minority identified by local clinical governance procedures. It was highly likely, though, that all doctors would be required to possess a personal "continuous professional development (CPD) portfolio", focused on their actual clinical responsibilities. A College working party, chaired by the President, was meeting regularly and personal CPD portfolios were being piloted in Nottingham and Gwent.

Dr Kendell then reported that the College's long campaign to persuade the Department of Health to reduce the bureaucratic load on psychiatrists was at last bearing fruit. A decision to abolish supervision registers and to simplify the Care Programme Approach would be announced within the next few months, the Department had set up a working party to consider the future of homicide inquiries and managers' reviews were unlikely to survive the 
review of the Mental Health Act. He also told the meeting that the government's consultation paper on dangerous people with severe personality disorders and the Department of Health's (1999) National Service Framework for Adult Mental Illness would probably both be published later that month. Both would have major implications for the College.

Finally, Dr Kendell reported that 84 NHS trusts had now signed up for the College Research Unit's (CRU) Clinical Governance Support Service and that the first of the two evidence-based guidelines for the management of acute schizophrenia commissioned by the Department of Health from the CRU and the British Psychological Society had now been delivered to the Department. It dealt with the relative merits of conventional and atypical neuroleptics and would probably be published under the imprimatur of the new National Institute for Clinical Excellence before the end of the year.

\section{Registrar's Report}

The Registrar reported that it had, in the past, been customary to gallop at speed over all the events of the last year. Instead, Dr Shooter intended to pick out those issues that had helped to dispel some entrenched mythology.

It had been said that the College was too arthritic to respond to the immediacy of the moment. The Registrar declared this not to be true. In just a few weeks' consultation, the College managed what it took the old Percy Commission two years to cover, and it awaited the Government's reaction to its far-reaching proposals for reform of mental health legislation.

It was also said that the College was too arrogant to be properly in touch with the feelings of patients. Again, this was not true. The Patients' and Carers' Liaison Group was represented on all key committees of the College, and had helped lay down clinical guidelines, taken the police to task over the use of CS spray, led sessions on conference programmes, campaigned for its experience to be used in psychiatric training and would host this year's meeting of similar groups from other Royal Colleges. Factsheets reminding patients and clinicians of the communication that should underpin all good therapeutic relationships were a warning to the Department of Health of the resources needed for good communications to be done properly.

It was said that the College approached everything with a reactionary traditionalism. Again, Dr Shooter declared this not to be true. The College had met controversy head-on, with rational, public argument - whether that was through Working Party reports on Confidentiality or Advocacy, responses to the GMC's demands for standards in working with vulnerable patients, or tackling Jack Straw's proposals for the management of dangerous personality disorder. Dr Shooter felt such issues could present a rough ride, but an exciting one.

It was said that the College was too fragmented to hold together in difficult times. Again - this was not true. While the membership may still reach first for their Faculty identity, the College was pledged to revitalise the Divisions with administrative aid and devolved powers. The Birmingham Conference had been an outstanding example of the membership coming together, as psychiatrists first and foremost, offering different perspectives to common issues.

Finally, it was said that the leadership of the College was too aloof. Once again - not true. Dr Shooter believed that College Officers walked a difficult tightrope between external lobbying and internal affairs. As the College welcomed $\mathrm{Dr}$ Robert Kendell's successor, Professor John Cox as its new President, it had said goodbye to $\mathrm{Dr}$ Kendell, whom the Registrar described as the "master of the highwire". Like all good showmen, Dr Kendell had gone just at the moment everyone was shouting for more!

\section{Treasurer's Report}

For information, the Treasurer started with two pie charts which he said represented a snapshot of financial activity. These were also available in the Annual Report. While informative, and sufficient for most purposes, they did not tell the whole story and needed to be supplemented by a brief description of important themes. In future it was intended there be one page only of annual accounts including pie charts in the Annual Report rather than full accounts. The latter currently occupied up to 18 pages of the Annual Report. However, trustees would receive full accounts which would be available as well to members by request to the Head of Financial Services.

The Treasurer reported that the College had had a good year financially. The surplus achieved was over $£ 450000$ which was largely due to the income generated by the Publications Department with net incoming resources of almost $£ 330000$. There was also a non-recurring VAT rebate of $£ 150000$.

Professor Kolvin said there were three main sources of College funds - members' subscriptions, publications and conferences. He thought it appropriate to make a special reference to the contribution of the Publications Department. It not only paid its own way, but there were overt and also hidden contributions to College funds. Publications carried the full cost of journals for 
members estimated at $£ 150000$. Further it contributed an additional major sum to College funds already alluded to. However, this very major contribution could not be guaranteed year by year. For example, publications were not yet sure of the impact of electronic publication. He also stated there were some concerns about losses incurred by some College conferences and solutions were being explored.

The Treasurer added, in summary, since the mid-1990s there had been a year by year improvement in the financial health of the College and which had allowed many new ventures to be embarked upon:

(a) The College had begun to look rather shabby and it had been necessary to initiate a redecoration and refurbishment programme.

(b) It had been possible to invest heavily in information technology.

(c) It had been possible to invest in College property.

(d) It had been possible to be more generous to the Research Unit (which incidentally had gone from strength to strength).

(e) It had been possible to give support to some important projects such as the Changing Minds campaign.

(f) It had found funds to allow the Irish, Welsh and Scottish divisions to operate administratively on a semi-autonomous basis.

Finally, there was a proposal to introduce a facility whereby members in UK and Ireland who paid by direct debit could opt to pay their subscriptions by two instalments.

This was Professor Kolvin's last year as Treasurer and, he added, he needed to acknowledge the skills of the Finance staff, particularly Mr Paul Taylor, the Head of Financial Services, the advice and interest of Mrs V. Cameron, the College Secretary, and the support of the President.

\section{Dean's Report}

Professor Katona opened his Report by recalling that, when he took up post as Dean just a year ago, his predecessor John Cox told him that it would take about a year to learn the ropes. The Dean hoped that he had learned at least some of them by now!

Professor Katona's main commitment as Dean was to develop an Educational Strategy and agenda for major educational developments within the College in the next few years. He saw this as particularly important in the present context of the very rapid changes currently being experienced in our educational needs and circumstances. He reported that this work had now been completed, with very considerable help and support from two Sub-Deans, Professor David Cottrell and Dr Kingsley Norton and from Dr Anne Dean, Head of Postgraduate Educational Services. The document made explicit the College's commitment to principles of adult learning and to the concept of 'lifelong learning'. The Dean was delighted that the educational strategy, together with a detailed timetable for action, had been endorsed not only by the relevant educational committees but also by the Court of Electors. Key elements of the strategy included:

(a) A thorough review of the MRCPsych examination - this was already well under way.

(b) The development of clear educational objectives for the (very welcome) new mandatory placement in Child and Adolescent Psychiatry and/or the Psychiatry of Learning Disability.

(c) The development of a clear MRCPsych curriculum with attainable and assessable educational goals.

(d) Identification of appropriate 'exit skills' for specialist registrars through collaboration between the Regional Deaneries, the Education Committee, the Higher Specialist Training Committee and the Collegiate Trainees Committee.

(e) Recasting the College's CPD programme to make the process more relevant and involving for individuals as well as more in keeping with the demands of clinical governance and of revalidation.

In connection with the last of these, one decision Professor Katona had taken last year was to make the development of CPD a high personal priority, and he took over from Professor Gethin Morgan in January 1999 as Director of CPD. In the light of the increasing importance and public profile of CPD within clinical governance and within the developing framework of revalidation, Professor Katona believed his decision was right. He stressed that he owed a very large debt of gratitude to Professor Morgan for all his work in developing CPD structures. Professor Katona expressed his delight that the Court of Electors had now agreed that participation in CPD would - from January 2000 - be compulsory for educational supervisors. What was more important was that CPD must also become more educationally meaningful and more tailored to individual and to service needs. The Dean stated that the College was currently developing a 'personal CPD portfolio' approach, which should move considerably further towards ensuring that 
CPD was relevant, and should also fit in well with revalidation structures.

One further promise the Dean made upon election last year was that he would be available to listen and respond to the views of all interested members, fellows and affiliates. One way of doing this was through the face to face or telephone 'Dean's Surgery' he held on alternate Friday afternoons. He urged anyone interested in participating to contact him via his secretary, Lena Hartley, on extension 139 at the College.

The Dean noted that the educational strategy on which he and his colleagues had embarked was an ambitious one. He was confident. however, that with the tremendous enthusiasm and willingness to collaborate of the individuals and committees involved, that all aspects of the strategy could be implemented over the next three or four years.

In conclusion, and on a more personal note, the Dean revealed that the past year had not been an easy one for him at home. One of his children had developed an early onset bipolar disorder and, only after several months was his acute psychosis now slowly resolving. Professor Katona said that this terrible experience had taught him more than he could have imagined about the reality and the stigma of mental illness as a family experience. He wished to close by thanking the many colleagues and friends for the support they had given him and his family during this very difficult period.

\section{Editor's Report}

Professor Wilkinson commended the performance of College publications during 1998 to Fellows and Members, and thanked his fellow editors, the Publications Department - particularly Mr Dave Jago, Head of Department - and all those who had contributed to the continuing success of this crucial area of the College's work.

Professor Wilkinson announced that the assessors who had undertaken most assessments during 1998/99 were:

Professor Tim Crow (26);

Professor Julian Leff (22);

Professor Peter Tyrer (20):

Dr D. D. R. Williams (19);

Dr John Cookson and Dr Frank Holloway (both 17).

Thanks were due to these individuals for their important contribution.

\section{Librarian's Report}

Dr Pullen reminded Members that he had announced intended changes to the Library at the Business Meeting at last year's Annual General Meeting held in Belfast. His proposal to transform the Library into an Information
Service had been approved by the College Council in the autumn of 1998, and were now being implemented. The changes to the library were being overseen by a short-life project group, and two new staff had been appointed as Helpline Information Officer and Helpline Information Administrator. Specifications for the new hardware and software were being finalised, and architects had produced several designs which were currently being costed.

Dr Pullen hoped that by spring 2000, the book collection would have been culled, the journal collection significantly reduced and the new Service fully functioning. The Service would provide up to date, accurate information about College policy, activities and events to callers, in addition to providing information on psychiatry and mental health topics in general.

In inclusion, Dr Pullen reported that further information about these changes would be given in future issues of the Psychiatric Bulletin and via newsletters.

\section{Election and introduction of Honorary Fellows}

The following were unanimously welcomed to the Honorary Fellowship.

\section{Professor Charles Anthony Butterworth} (introduced by Professor Francis Creed)

Professor Butterworth has been nominated by the Court of Electors to be an Honorary Fellow of the Royal College of Psychiatrists (in July 1999) in recognition of his unique contribution to psychiatric nursing.

Professor Butterworth began his career in psychiatric nursing as a trainee in a psychiatric hospital at Huddersfield. This site has now become a university. This transformation from a traditional psychiatric nursing training to a university education epitomizes Tony's contribution to the speciality.

Following his psychiatric nurse-training, Professor Butterworth trained and worked as a general nurse at the Manchester Royal Infirmary. It is at this Trust that Tony Butterworth is now a Non-Executive Director. During the early 1970s, he worked at the same hospital as Professors David Goldberg and Neil Kessell and perhaps this contact inspired him to take up an academic post at Manchester Polytechnic - this has now become a university. For the last 12 years, he has held the Queen's Nursing Institute Chair of Community Nursing at the Victoria University Hospital, where he has been Dean of the School of Nursing. Midwivery and Health Visiting for several years.

For over 20 years, Professor Butterworth has been very active in both research and education. 
His four books have been concerned with caring for the mentally ill in the community and clinical supervision and mentorship in nursing. His writings have also included the assessment of stress in nursing and health visiting and how clinical supervision can reduce this. It is not surprising, therefore, that he has supervised at least 10 nurses to a successful $\mathrm{PhD}$ - many of these are now themselves professors.

His research grant income over the last 10 years exceeds £2.5 million, which has funded research concerning the supervision and education experience of community psychiatric nurses, telephone consultation involving community nurses and health visitors and the nursing of people with AIDS and HIV.

Possibly his best known recent work concerns the training of community psychiatric nurses (CPNs) in psychosocial intervention techniques this 'Thorn' initiative was pioneered in Manchester and London and has now led on to a regionwide training scheme so that CPNs can receive training in the appropriate skills in caring for the seriously mentally ill - family intervention, case management and some cognitive interventions.

Professor Butterworth has also advised the Bethlem and Maudsley, the University Research Assessment Exercise and the Culyer Research and Development Committee on matters of nursing research. He has won education and training contracts in competition with other Universities in the UK, which total more than $£ 10$ million. These contracts are to provide for initial and continuing education for nurses, midwives, including community nurses and mental health professionals.

As a representative of nursing in a very large university, Professor Butterworth's contribution has developed further the formidable reputation of nursing research and teaching at Manchester. He has a well deserved reputation for recruiting to Manchester some of the best senior academic nurses in the UK. He has chaired the University Academic Standards Committee and, as in many other contexts, he is known for his openness and fairness of discussion and decision-making. He has recently become a Pro-Vice Chancellor at the University, which reflects the high esteem in which he is held by senior colleagues at the University. He has responsibility for several areas of external relationships, most notably with the NHS. This testifies to his understanding of the very different managerial spirals of the University and the NHS and to his very considerable negotiating skills.

At a national level, he has sat on Committees to consider priorities for mental illness research, to review the provision of mental health nursing in England. He has sat on the panel to advise the work of the Audit Commission on Services for People with Mental Illness. He is a past Chairman of the Community Psychiatric Nurses Association and advises the North West Regional Health Authority, the Royal Marsen Academic Nursing Unit and the Central Manchester Healthcare Trust, on aspects of nursing education.

He is currently Chairman of the Council of Deans and Heads of UK University Faculties of Nursing, Midwifery and Health Visiting.

On the international scene, Tony Butterworth is known for his work as Director of the World Health Organisation (WHO) Collaborating Centre based at the Untversity of Manchester for reference, research and education in primary health care nursing. He is the Secretary General to the global network of WHO Collaborating Centres for Nursing, which extend over 18 member countries.

The honour bestowed upon Professor Butterworth at Honorary Fellow of this College is added to his other honours - Fellow of the Royal College of Nursing, Fellow of Academy of Medical Sciences and Fellow of the Royal Society for the Arts. A few years ago, he was honoured as Commander of the British Empire. His Honorary Fellowship is very well deserved.

\section{Dr Jerome H. Jaffe (introduced by Professor John Strang)}

I am delighted and honoured to have the opportunity to introduce Jerome Jaffe. Jerry Jaffe is a veritable giant of the addictions field. I know that Jerry feels honoured by the award, and the College also has the right to be duly honoured by the association. Let us reflect upon some of Jerry Jaffe's achievements. Firstly, Jerry Jaffe, the clinician. Jerry's grasp of the complexity of the condition no doubt draws on the breadth of his training, a first degree and then a Masters in Psychology before entering medicine and training in psychiatry while also conducting training and a Post-Doctoral Fellowship in Pharmacology. His contribution has always been notable for his respect for the individual suffering from addiction, indeed his compassion and caring for these individuals. From his early involvement in the federal hospital environment of working with prisoners with addiction problems in Lexington, his subsequent personal involvement with clinical developments included the exciting new (completely new) development of services in Chicago, and across Illinois, forming strategic alliances and breaking every rule in the book, while also setting up a broad based clinical programme and a research infrastructure that were to be profoundly influential on the years ahead.

Second, Jerry Jaffe the researcher. It is perhaps the diversity of his research contribution that is so extraordinary. Having trained with such people as Wikler and Isbell, his work includes experimental laboratory work with human volunteers 
with possible new drugs (such as l-methadyl acetate which, more than 30 years on, we would hope to see finally arrive in the UK later this year). But he also had a much broader concept of the laboratory - Chicago, indeed Illinois, became his laboratory. His exceptional grasp of the different aspects of the addiction problem are perhaps particularly strikingly evident in his wonderful chapters in edition after edition of Goodman and Gillman. Those of us who already know his chapters will be nodding wisely and reflecting on their excellence. To those who do not know these chapters, prepare yourself for a rich and satisfying treat. Of course Jerry is also the research creator, the man behind so many studies in different ways (such as the extraordinary studies of heroin addiction among US soldiers returning from Vietnam). Regardless of whether the published output bears his name, countless important studies undoubtedly bear his stamp.

Third, Jerry Jaffe the policy-maker. Jerome Jaffe was/is the definitive article, the Drug Czar. Evan at this distance in time, one can only gasp in astonishment at the achievements of the young 37-year-old Jerry Jaffe as he essentially created, over the course of two years, the huge and influential drug research and treatment systems which have been so important in the US and internationally. Even from this side of the Atlantic, one cannot help but be impressed by his account of the extraordinary events: and I quote from the journal interview with him (published in Addiction in January this year):

The President (Richard Nixon) asked me to come in to the Cabinet Room, and that was unusual. I had never been in the Cabinet Room before. And there was the leadership of the Congress (the Senate and the House of Representattves). The President explained that he was going to create the Special Action Office. Then he pointed at me and said Dr Jaffe is going to run this office. I was 37 and it never occurred to me to say Mr President, who told you that? (Jaffe, 1999)

From this point we can see the rapid establishment of a national network of structured oral methadone maintenance programmes, and of therapeutic communities (and a new therapeutic optimism). Also Jerry Jaffe was able to establish the framework for NIDA, the National Institute on Drug Abuse and kick-start the American research machine to drive the extraordinary output that has followed.

Finally, I would like to talk of Jerry Jaffe, the man. His encyclopaedic knowledge of the field. His understanding of the different significances of findings in different contexts and times. His grasp of the interplay between the drug, the individual and the environment. But perhaps, above all, his tolerance and generosity. His tolerance of our slowness or difficulty in grasping the significance of some new information; and his generosity in helping us work our way through, (at a place that must seem painfully slow to him), helping us work our way through to a fuller understanding. Those of us who have been working on the special Joint College Working Group currently under way and chaired by our President Dr Kendell have enjoyed (I certainly have), have certainly been stretched by, and have enjoyed working with Jerry Jaffe on this task. As so it is with great personal and professional pleasure that I introduce Jerome Jaffe to you.

Professor William Alwyn Lishman (introduced by Professor Maria Ron)

It is a great pleasure to introduce Professor Alwyn Lishman as an Honorary Fellow of our College. It is also a unique opportunity to tell you about the man who has been my mentor and friend for many years. The name Lishman is now synonymous with neuropsychiatry and it would be difficult to think of anybody who has done more to enhance the standing of his discipline or who is a more revered teacher. Things could have turned out to be very different. For Alwyn Lishman never even intended to be a doctor. Doubtless he would have become famous as a musician or in another field of endeavour, but then we would not be here today. Let me tell you how our good fortune came about.

William Alwyn Lishman was born in Houghtonle-Spring, a small mining village near Durham. For a few generations the Lishman family had been in the business of candle-making and there were few connections with medicine until Alwyn's father became a medical student before the First World War. Unfortunately the onset of the war prevented him from completing his studies and he went into the family business. I think we should be grateful because this unfulfilled paternal wish was later to influence Alwyn's career choice. Alwyn had always said that he never wanted to be a doctor, and being a very good musician from an early age his interests were artistic rather than scientific. But Alwyn has always been interested in people and when parental expectations pushed him to do something scientific he considered medicine to be the best of a bad lot.

Alwyn went to medical school in Birmingham and became deeply attracted to the neurosciences, but even at that point he was still far from contemplating a career in psychiatry. He first toyed with the idea of being a neurosurgeon and later, far more seriously, he considered being a neurologist. During his National Service he was posted to the head injury hospital in Oxford. He had the opportunity to work with famous neurologists like Ritchie Russell and Sir Charles Symonds and published important 
papers on brachial neuropathies and reflex epilepsy. His interest in the cognitive and behavioural sequelae of brain trauma dates from that period. By 1960 a successful career in neurology looked a foregone conclusion and very tempting offers started coming his way. However, neurology was becoming very sterile for a man interested in people. Alwyn wanted to treat patients and at the time few treatments were available in neurology and he started to look elsewhere for a more fulfilling career. The idea of doing psychiatry had already occurred to Alwyn, but it was the example of his good friend Bob Cawley, who sadly is no longer with us, that finally launched his career in psychiatry. Bob and Alwyn had been close friends since their medical school days. By 1960 Bob had started his training at the Maudsley and finding it very enjoyable tried to persuade Alwyn to join him there. Curiosity, always a strong drive for Alwyn, got the better of him and he decided to give it a try. Fortunately for us psychiatry satisfied both his intellectual curiosity and his interest in people and he never looked back.

The Maudsley provided Alwyn with something even more important, for it was there that he met his future wife. Marjorie, a social worker at the time, worked in an adolescent forensic unit where Alwyn was the senior registrar - that is how a most successful partnership started. Marjorie has given Alwyn support and encouragement for all these years, and we owe her a great deal.

Alwyn's first consultant appointment in 1967 was at the National Hospital, Queen Square, a fitting start for somebody so familiar with neurology. But Alwyn missed the Maudsley and in 1967 he accepted Sir Denis Hill's invitation to go back as his first assistant and the rest of his distinguished career took place there. After a few years as a full time consultant, his wish to devote more time to research and writing led him to take up an academic post at the Institute of Psychiatry. He became a reader in 1975 and in 1979 he was awarded the first personal Chair of Neuropsychiatry in the country.

It will be impossible to do justice to Alwyn's achievements, but let me quickly mention a few salient ones. He leaves behind an impressive and varied body of clinical research. His seminal work on the cognitive and behavioural sequelae of head injury was followed by studies of memory abnormalities in psychiatric populations and by his work on dementia. He also pioneered the use of imaging techniques in psychiatry. First to study chronic alcohol dependency and Korsakoffs psychosis and later the epilepsy-related neuropsychiatric problems. His painstaking research has always been inspired by clinical observation and those of us, who had good fortune of working with him, will always remember him as a superlative clinician. His ability to combine his detailed knowledge of the brain and the mind endeared him to clinicians of all persuasions who highly valued his opinion. His book Organic Psychiatry (Lishman, 1998), now in its third edition, is a distillation of that clinical wisdom. I know that Alwyn thinks is the most important thing he has done, but he is not alone in thinking so and it is specially pleasing to know that the British Medical Association named the best medical book in mental health in 1998. The third edition has been his post-retirement work and we all hope that in due course he can be persuaded to write a fourth.

This brief summary of Alwyn's clinical and academic achievements makes it easy to understand the pivotal role he has played in establishing neuropsychiatry as the flourishing discipline it is today. He has broadened its remit to incorporate not only the knowledge of the cognitive and behavioural manifestation of brain disease, but the cultural and social setting in which they occur. He has also been a very popular teacher attracting many gifted students over the years. Several of us now hold Chairs in Neuropsychiatry and it is difficult to think of a major psychiatric department where the discipline is not represented. I know that Alwyn takes special pride in his former students, but I also know how privileged those of us who have been his pupils feel. It is, therefore, very fitting for such an accomplishment teacher to have been the founder chairman of the British Neuropsychiatric Association (BNPA) and now its Honorary Life President. The BNPA, conceived as a multi-disciplinary association from its inception, has gone from strength to strength under his leadership. On his retirement as a chairman in 1992 the BNPA members numbered nearly 400 and close links had been forged with sister associations in the USA.

This long list of professional accomplishments has fortunately left some room for other activities. Music has always been a great joy for Alwyn and many of us had the fortune of hearing him play the organ at BNPA meetings. He also marked his retirement by giving an organ recital and I cannot think of many academics that could have done so.

All those who have come in contact with Alwyn Lishman will tell you of his kindness and wisdom and I hope this brief portrait has also given you a taste of his many achievements as a scientist. clinician and teacher. Mr President, ladies and gentlemen it is a great pleasure to present him to you for the Fellowship of our College.

Baron Rix of Whitehall and City of Westminster (introduced by Professor Sheila Hollins)

Lord Rix was born in Cottingham. Yorkshire, the son of a Hull shipowner. He moved to Hornsea 
when he was four, and grew up there. He intended to study medicine but his wartime experience changed his career direction. In 1947, after serving in the RAF, he formed his own theatre company, and married actress Elspeth Gray. In 1950 he began a 30-year run as an actor and manager at the Whitehall Theatre in the west end of London, and soon became a household name. The titles of the first two parts of his autobiography remind us of the genre with which he will always be associated-My Farce from My Elbow and Farce About Face.

Shelley, the eldest of Lord and Lady Rix's four children, has Down's syndrome. Their interest in working for people with a learning disability is of an intense, personal nature - and the Whitehall Theatre is also involved in this aspect of their lives, because Shelley was born soon after his first play Reluctant Heroes opened in Whitehall. Lord Rix's first committee meeting, for the then National Society for Mentally Handicapped Children, took place on the stage, and thus also began his second career as an advocate and guide for people with learning disabilities and their parents.

The relationship between parents and professionals is complex in any field of disability, and in the post-war years of the 1950s, when Lord Rix became involved as a parent in these matters, there was much to be critical of in terms of resource, attitudes and professional activity. Over the years there have been great changes in services and training that have led to a much greater coherence between parents and professionals. Mencap, headed by Lord Rix, took a lead in multi-agency working, and always recognised the mental health needs of people with learning disabilities. He established the Medical Committee, and worked closely with psychiatrists, paediatricians and others.

From 1980 to 1987 he was Secretary General of the National Society for Mentally Handicapped Children and Adults and became the Chairman in 1988, from which office he retired in 1998 . when he became President of the Royal Society. He was associated with many schemes to benefit people with learning disabilities and their families, including the Mencap Homes Foundation, the Mencap City Foundation, and with the three Open University courses on learning disability.

He was a founder member and past Chairman of the Independent Development Council for people with mental handicap, and is Chairman of the Friends of Normansfield, a past president of the Lord's Taverners, and served as Vice-Lord Lieutenant of Greater London for 10 years until 1997.

Lord Rix was closely involved in the cooperation between Mencap and Central Television which resulted in the presentation of a story concerning learning disability in the series
Crossroads, and the presenter of the Let's Go television series. Those $\mathbf{4 0}$ programmes were the first to be made specifically for people with a learning disability by a broadcasting authority. People Like Us and A Life of Our Own continued the tradition.

Lord Rix has had many honours over the years in recognition of his work for people with learning disabilities, including a $\mathrm{CBE}$, and honorary degrees. He was appointed Chancellor of the University of East London in 1997, and in 1998 he was made an Honorary Fellow of the Royal Society of Medicine. In 1986 he received a knighthood in the Queen's Birthday Honours List, and in 1992 he was made a Life Baron. He chose the title 'Baron Rix of Whitehall in the City, of Westminster and Hornsea in Yorkshire, because such a description captures some major events of his life.

Lord Rix has a long and distinguished record of improving the lives of people with learning disabilities. He achieved great fame through working in the theatre, and has used this influence to achieve many positive and humanistic effects. He has the respect of the political world, and speaks in the House of Lords on disability issues.

An Honorary Fellowship of the College is in honour of his personal contribution to this field of human and medical concern. By raising an awareness of the needs of people with learning disabilities, through the work of the Royal Society and a number of other activities, Lord Rix has promoted a proper medical study of learning disability with compassion as well as science. This has greatly supported the work of the Faculty of Psychiatry of Learning Disability, and this Fellowship is our way to offer our appreciation.

\section{Professor Robert Anderson Wood (introduced} by Dr Barbara Ballinger)

Professor "Bertie" Wood joined the Joint Committee on Higher Psychiatric Training (JCHPT) as the Committee of Postgraduate Medical Deans (COPMeD) representative in March 1995, becoming the Lead Dean for Psychiatry in the early stages of the implementation of the 'Calman' reforms. He took a lively interest in the progress of the reforms, acknowledging the particular problems presented by the staffing structure in the psychiatric specialities and pursuing compromises to deal with these. He contributed in his own inimitable manner with enthusiasm and at length to the discussions in the JCHPT as the reforms progressed. He was particularly supportive of the Royal College of Psychiatrists over the transition to the specialist registrar grade in 1996, and facilitated the resolution of some of the local difficulties that arose at that time. 
In addition to this very specific contribution to the Royal College of Psychiatrists, Professor Wood has taken a great interest in the development of training opportunities for women doctors, and this issue is particularly relevant to training in psychiatry where there is a relatively high proportion of female trainees. He has also been very supportive of postgraduate training in psychiatry, both in his local area as Postgraduate Medical Dean and in Scotland as a whole in his role as a member of Council of the Scottish Council for Postgraduate Medical and Dental Education.

Professor Wood was a distinguished physician in Tayside who was always interested in the wider issues of postgraduate training which he then pursued with vigour as Postgraduate Medical Dean in Aberdeen. He has contributed at a national level to postgraduate training on COPMeD, convening the COPMeD Working Party on national documentation for pre-registration house officer post approval and pre-registration house officer appraisal. He has also continued to be involved in research, coordinating the Scottish Colleges study into consultant continuing medical education.

In conclusion, Professor Wood is a distinguished colleague in postgraduate medical education whose contribution to training and development in psychiatry is appropriately acknowledged by the award of an Honorary Fellowship of the Royal College of Psychiatrists.

\section{References}

Department OF HEALTH (1999) National Service Framework for Mental Health: Modern Standards and Service Models. Executive Summary. London: Department of Health.

JAFFE, J. H. (1999) Conversation with Jerome H. Jaffe. Addiction, 94, 13-30.

Lushman, W. (1998) Organic Psychiatry: The Psychological Consequences of Cerebral Disorder (3rd edn). Oxford: Blackwell.

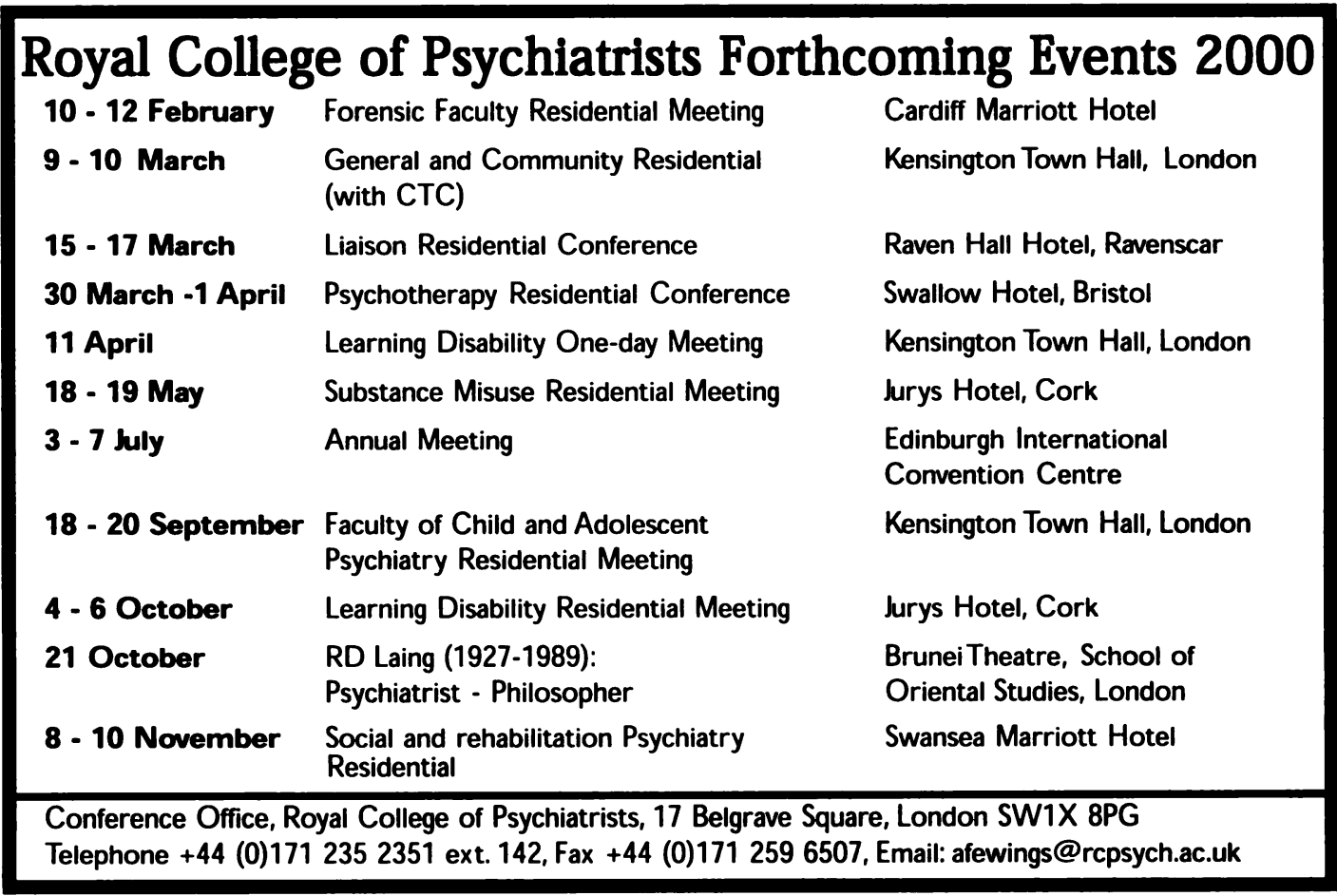

